\title{
Leucyl-tRNA synthetase from Thermus thermophilus. Purification and some properties of the crystallizing enzyme
}

\author{
A. D. Yaremchuk, O. I. Gudzera, S. P. Egorova, D. I. Rozhko, \\ I. A. Kriklivy, M. A. Tukalo
}

Institute of Molecular Biology and Genetics, National Academy of Sciences of Ukraine 150 Academician Zabolotnoho vul., Kyiv, 03143, Ukraine

\begin{abstract}
Leucyl-tRNA synthetase from Thermus thermophilus (LeuRSTT) was purified to homogeneity using a five-step purification procedure. The enzyme was characterized and crystallized. Molecular mass determinations of the native and denatured proteins indicate monomeric structure of LeuRSTT with the molecular mass of about $101 \mathrm{kDa}$. The protein obtained is remarkably thermostable and retains $97 \%$ of its initial aminoacylation activity after I hour of incubation at $88{ }^{\circ} \mathrm{C}$. Crystals of LeuRSTT were obtained from ammonium sulfate solution by the vapour diffusion techniques. The crystals quality was improved by crystallization from the precipitate.
\end{abstract}

Introduction. Aminoacyl-tRNA synthetases (aaRSs) catalyze the specific esterification of an amino acid to the $3^{\prime}$-end of its cognate tRNA. Through a two-step reaction, aaRSs use first ATP to form the activated intermediate, aminoacyl-adenylate, and then transfer the amino acid to the $3^{\prime}$-end of their cognate tRNA. The reaction is highly specific, although in some cases, to ensure the fidelity of the genetic code translation, the aaRS relies on an editing activity to hydrolyze misactivated amino acids which are similar to the cognate amino acid $[1,2]$. The family of twenty aaRSs are divided into two distinct classes of ten enzymes each on the basis of the primary and tertiary structures information [3, 4$]$. Also, all tRNA molecules can be classified into two types according to the length of the variable arm. Type I tRNAs (most of tRNA molecules) have a short variable arm comprising four or five nucleotides. Type II tRNAs ( $\mathrm{RNA} \mathrm{A}^{\mathrm{Ty}}$ from eubacteria and organelles of lower eukaryotes, tRNA ${ }^{\text {Leu }}$ and $t R N A^{\text {Ser }}$ ) have a long variable arm composed of more than ten nucleotides.

Leucyl-tRNA synthetase (LeuRS) is a monomeric class I enzyme which recognizes type II tRNA. It was

(C) A. D. YAREMCHUK, O. I. GUDZERA, S. P. EGOROVA D. I. ROZHKO, I. A. KRIKLIVY, M. A. TUKALO, 2001
Shown by mutational studies that Escherichia coli LeuRS recognized tRNA ${ }^{\text {Leu }}$ in a manner different from the standard recognition mode [5]. Only the discriminator base A73 is required for the basespecific recognition by LeuRS while the anticodon, the variable stem loop and the acceptor stem sequences are not essential for the specific recognition by LeuRS. To define the recognition mode and structural identity elements of tRNA ${ }^{\text {Leu }}$ by LeuRS as well as to get detailed information on substrate specificity and enzyme mechanism it is necessary to determine the crystal structure of the enzyme alone and in the complex with substrates. So far crystal structures of sixteen from twenty different synthetases have now been determined together with a variety of substrate complexes $[6,8]$. LeuRS is one of four aaRSs which crystal structure is not known yet. Here, we report the purification, some properties and crystallization of LeuRSTT.

Materials and Methods. Materials DEAE Sepharose Fast Flow, Heparin Sepharose CL-6B were from «Farmacia LKB Biotechnology» (Sweden). Hydroxylapatite was from «Bio-Rad» (USA). TSK-Gel HW65 from «Toyo Soda MFG» (Japan). Polypepton and yeast extract were from «Difco» (USA). Unfractionated tRNAs from $E$. coli, protease inhibitor cock- 
tail tablets (completeTM) and phenylmethylsulfonyl fluoride were from «Boehringer Mannheim» (Germany). Protein markers for molecular mass determinations, HEPES and ATP were purchased from «Sigma Chemical Co.» (USA). ${ }^{14} \mathrm{C}$-labelled leucine was from «Amersham, UK» (Great Britain). Ammonium sulfate, polyethylene glycol, MES and bis-Trispropane were from «Fluka, Biochem.» (Switzerland).

Purification of $T$. thermophilus LeuRS and $t R N A^{\text {Leu }}$. The T. thermophilus (strain HB8 or HB27) cells were harvested by centrifugation, washed and disrupted by a French Press in $100 \mathrm{mM}$ Tris- $\mathrm{HCl}$ buffer, containing $2 \mathrm{mM}$ dithiothreitol, $0.1 \mathrm{mM}$ EDTA, $1 \mathrm{mM}$ phenylmethylsulfonyl fluoride, completeTM (1 tabl. $/ 25 \mathrm{ml}$ extraction buffer), $5 \mathrm{mM}$ $\mathrm{MgCl}_{2}$ and $1 \mathrm{mM} \mathrm{NaN}$. The extract was centrifuged for 2 hours at $105000 \mathrm{~g}$ and the supernatant was subjected to $30-65 \%$ ammonium sulfate fractionation. The precipitate containing LeuRS activity was dissolved in $20 \mathrm{mM}$ Tris- $\mathrm{HCl}$ buffer, $\mathrm{pH} 7.5$ containing $5 \mathrm{mM} \mathrm{MgCl}_{2}, 0.1 \mathrm{mM}$ phenylmethylsulfonyl fluoride, $2 \mathrm{mM}$ DTT, $1 \mathrm{mM} \mathrm{NaN}_{3}$ (buffer A), dialyzed against buffer $\mathrm{A}$ and absorbed on a DEAESepharose column $(5 \times 55 \mathrm{~cm})$ equilibrated with buffer A. The LeuRS was eluted with $2 \times 2.5 \mathrm{~L}$ linear gradient of $0.03 \mathrm{M}$ to $0.3 \mathrm{M}$ sodium chloride in buffer A. The fractions containing LeuRS activity were salted out by ammonium sulfate (50\% saturation) and applied to a Toyopearl HW-65 column $(3 \times$ $\times 80 \mathrm{~cm})$ equilibrated with $40 \%$ of ammonium sulfate in buffer $A$. The proteins were eluted with $2 \times 2$ $L$ gradient of $40-10 \%$ saturation ammonium sulfate in buffer A. Fractions containing LeuRS activity were pooled, dialyzed and chromatographed on a hydroxylapatite column $(3 \times 40 \mathrm{~cm})$ with $2 \times 2 \mathrm{~L}$ potassium phosphate buffer linear gradient from $0.01 \mathrm{M}$ to $0.25 \mathrm{M}$ (pH 7.9). After dialysis in buffer $\mathrm{A}$ of the active fractions the enzyme was loaded on a Heparin Sepharose CL-6B column $(1 \times 40 \mathrm{~cm})$. A $1.0 \mathrm{~L}$ linear $0-0.25 \mathrm{M} \mathrm{KCl}$ gradient in buffer A was used to elute the LeuRS. All steps of the enzyme purification were carried out at $4{ }^{\circ} \mathrm{C}$.

T. thermophilus $\mathrm{tRNA}^{\text {leu }}$ was purified from bulk tRNA using BD-cellulose, anion-exchange DEAE 5PW (HPLC, «Beckman», USA) and C8 reversephase chromatography (I. Krikliviy, D. Rozhko and M. Tukalo, unpublished results).

Enzyme activity. The aminoacylation reaction mixture contained $50 \mathrm{mM} \mathrm{Na-Hepes,} \mathrm{pH} 7.3,15 \mathrm{mM}$ $\mathrm{MgCl}_{2}, 30 \mathrm{mM} \mathrm{KCl}, 0.5 \mathrm{mg} / \mathrm{ml}$ bovine serum albumin (BSA), $7 \mathrm{mM}$ ATP, $0.1 \mathrm{mM}$ DTT, $0.096 \mathrm{mM} \mathrm{L-}$ $\left[{ }^{14} \mathrm{C}\right.$ lleucine («Amersham») diluted with non-labelled amino acid to $68420 \mathrm{cpm} / \mathrm{nmol}, 4 \mathrm{mg} / \mathrm{ml}$ unfractionated $E$. coli tRNA and $0.001-1 \mathrm{mg} / \mathrm{ml}$ of protein depending upon the purity of the enzyme. The reaction was conducted at $55{ }^{\circ} \mathrm{C}$ for $1 \mathrm{~min}$ and the samples were placed on GF/A filters. The filters were washed three times in $5 \%$ trichloroacetic acid, ethanol, 50:50 (vol/vol.) ethanol/ether and the radioactivity was measured by liquid scintillation counting.

The $K_{m}$ values for ATP, leucine and tRNA ${ }^{\text {lew }}$ were determined at $65^{\circ} \mathrm{C}$ in the standard mixture containing $10 \mu \mathrm{g} / \mathrm{ml}$ of LeuRSTT and varying concentration of ATP $(10-300 \mu \mathrm{M})$, leucine $(0.5-$ $50 \mu \mathrm{M})$ or tRNA $(0.05-2.5 \mu \mathrm{M})$ respectively (using ENZFITTER programme).

The molecular mass determination. The molecular mass of the enzyme was determined by gel filtration on a column $(1.1 \times 72 \mathrm{~cm})$ of Sephadex G 200 and by PAGE under native and denaturing conditions. Under native conditions it was conducted in $5 \%$ and $6 \%$ polyacrylamide gels. Under denaturing conditions it was conducted in $12.5 \%$ polyacrylamide gel in the presence of $0.1 \%$ SDS as described by Laemmli [9].

Measurements of thermal stability of LeuRS. The heat stability of the aminoacylation activity of LeuRSTT was analyzed by incubating $100 \mu 1$ of the enzyme solution $(1.5 \mathrm{mg} / \mathrm{ml})$ in $100 \mathrm{mM}$ Na-Hepes, pH 7.3 containing $15 \mathrm{mM} \mathrm{MgCl} 2$ with or without the small substrates at the indicated concentration. At various times, $10-\mu 1$ aliquots were removed, diluted in cold enzyme dilution buffer containing $100 \mathrm{mM} \mathrm{Na}$ Hepes, pH 7.3, $2 \mathrm{mM}$ DTT, $10 \%$ glycerol, $15 \mathrm{mM}$ $\mathrm{MgCl}_{2}$ and $5 \mathrm{mg} / \mathrm{ml}$ BSA. The remaining aminoacylation activity was determined by initial rate measurements as described above.

Crystallization procedure. Crystallization trials were conducted at different constant temperatures (6, 12 , and $20{ }^{\circ} \mathrm{C}$ ) using the hanging-drop vapor-diffusion method. The drops of 4-10 $\mu 1$ were allowed to equilibrate against $0.8 \mathrm{ml}$ reservoir solution. Conditions such as the nature of the precipitant, the composition and $\mathrm{pH}$ of the buffer and the concentration of the protein were varied.

Results and Discussion. LeuRSTT was purified from both HB8 and HB27 strains to homogeneity using a five-step purification procedure (Table 1). The final yield was approximately $20 \mathrm{mg}$ of the pure enzyme from $520 \mathrm{~g}$ cells with a specific activity of $2212 \mathrm{U} / \mathrm{mg}$ ( $1 \mathrm{U}$ of the enzyme catalyzes the formation of $1 \mathrm{nmol}$ leucyl-tRNA/min at $65^{\circ} \mathrm{C}$ ). Gel filtration gives $M$, of $100 \mathrm{kDa}$. PAGE under native conditions reveals an apparent $\mathrm{M}_{r}$ of $102 \mathrm{kDa}$. SDS/PAGE shows a single band corresponding to a polypeptide chain of about $101 \mathrm{kDa}$. The kinetic constants of the aminoacylation reaction catalyzed by 
YAREMCHUK A. D. ET N.

Table I

Purification of leucyl-tRNA synthetase from T. thermophilus $H B 8$

\begin{tabular}{|c|c|c|c|c|c|}
\hline Purlfication step & Total protela, ms & $\begin{array}{c}\text { Specific actulty, } \\
\text { U/mg }\end{array}$ & Total activity, $\mathrm{v}$ & Purification, fold & vield, $\%$ \\
\hline Crude extract* & 35230 & 0.72 & 25319 & 1 & 100 \\
\hline Ammonium sulfate fractionation & 12364 & 1.93 & 23826 & 2.7 & 94 \\
\hline DEAE-Sepharose & 1284 & 18.54 & 23800 & 25.7 & 94 \\
\hline Toyopearl HW-65 & 354 & 64.58 & 22859 & 89.7 & 90 \\
\hline Hydroxylapatite & 42 & 534.71 & 22458 & 742.7 & 89 \\
\hline Heparin Sepharose & 19.8 & 1117 & 22123 & 1551 & 87 \\
\hline
\end{tabular}

*Obtained from $520 \mathrm{~g}$ cells.

Table 2

Kinetic constants of aminoacylation reaction catalyzed by LeuRS from $T$. thermophilus at $65^{\circ} \mathrm{C}$

\begin{tabular}{|c|c|c|c|}
\hline \multicolumn{3}{|c|}{$K_{\text {ma }}, M$} & \multirow{2}{*}{$k_{\text {cat }} \min ^{-1}$} \\
\hline ATP & Leucine & $\mathrm{tRNA}^{\text {leu }}$ & \\
\hline $5.5 \cdot 10^{-5}$ & $9.1 \cdot 10^{-6}$ & $3.7 \cdot 10^{-7}$ & 220 \\
\hline
\end{tabular}

LeuRSTT for ATP, leucine and tRNA ${ }^{\text {leu }}$ are reported in Table 2. There is no significant difference in $K_{\mathrm{m}}$ and $k_{\text {cat }}$ values of LeuRSTT for all three substrates compared with those of LeuRS from $E$. coli [10]. The optimal temperature for the tRNA aminoacylation reaction catalyzed by LeuRSTT is about $70^{\circ} \mathrm{C}$ for tRNA ${ }^{\text {Lu }}$ from $T$. thermophilus and about $65^{\circ} \mathrm{C}$ for tRNA $^{\text {Lei }}$ from $E$. coli (Fig. 1). The thermal stability of the enzyme was investigated in the range from 50 to $90^{\circ} \mathrm{C}$. The enzyme is remarkably thermostable. It retains $100 \%$ of its ability to aminoacylate tRNA after $1 \mathrm{~h}$ of incubation at $85^{\circ} \mathrm{C}$ (data not shown) and about $97 \%$ at $88{ }^{\circ} \mathrm{C}$. ATP and leucine alone do not affect the thermal inactivation of the enzyme at $88^{\circ} \mathrm{C}$. Surprisingly, when ATP and leucine or ATP, leucine and inorganic pyrophosphate are present together significant inactivation of LeuRS occurs after $1 \mathrm{~h}$ at $88^{\circ} \mathrm{C}$ (Fig. 2). In contrast, the protection of GlyRS from thermoinactivation by ATP, glycine or glycyladenylate was shown for $T$. thermophilus GlyRS [11], ATP or tyrosyladenylate for TyrRS, histidine or histidyladenylate for HisRS and prolyladenylate for ProRS from T. thermophilus (Yaremchuk et al., unpublished results). In all these cases the protection of the aaRS from thermal inactivation by substrates correlates with conformational changes of the enzyme promoted by substrates binding ([11], Cusack S., Yaremchuk A. and Tukalo M., unpublished results).

To study the mechanism of amino acid recognition and activation and the specific recognition of cognate tRNA by $T$. thermophilus LeuRS we tried to crystallize this enzyme alone and in complex with the substrates. Initial screening of crystallization conditions was conducted using a sparse matrix sampling reagents from Hampton Research (Crystal screen 1 and 2, Grid screens including ammonium sulfate,

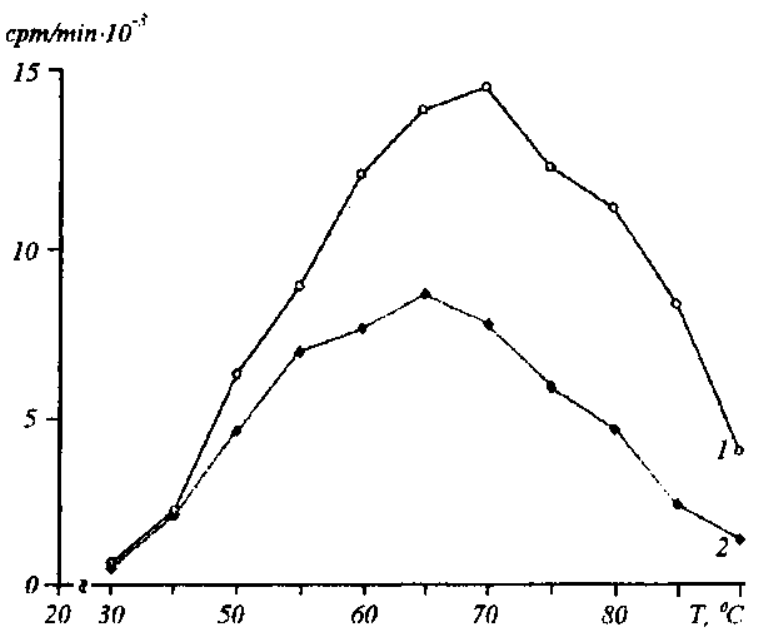

Fig. 1. Dependence of the rate of tRNA aminoacylation catalyzed by LeuRSTT on temperature: $1-T$. thermophilus tRNA ${ }^{\text {Leu }} ; 2-E$. coli tRNA ${ }^{\text {Leu }}$ 


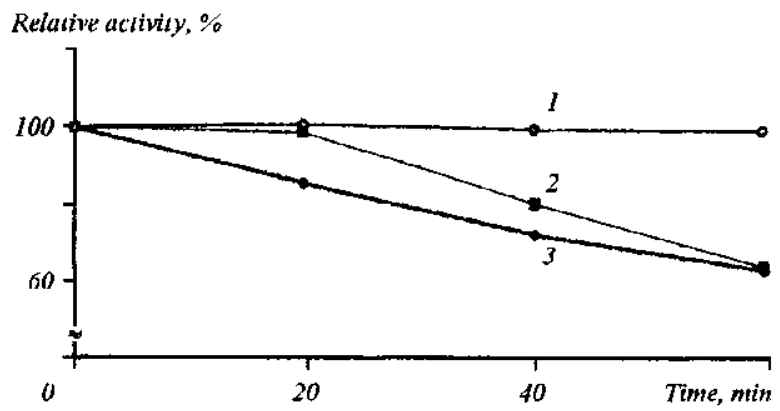

Fig. 2. Thermal stability of LeuRSTT in the absence and in the presence of small ligands. The enzyme $(1.5 \mathrm{mg} / \mathrm{ml})$ was incubated at $88{ }^{\circ} \mathrm{C}$ in $100 \mathrm{mM} \mathrm{Na}$-Hepes, $\mathrm{pH} 7.3$, and $15 \mathrm{mM} \mathrm{MgCl}_{2}$ either in the absence $(I)$ or in the presence (2) of $1 \mathrm{mM} \mathrm{ATP}$ and $2 \mathrm{mM}$ leucine and in the presence (3) of $1 \mathrm{mM} \mathrm{ATP,} 2 \mathrm{mM}$ leucine and 1 $\mathrm{mM} \mathrm{PP} \mathbf{P}_{i}$. The remaining activity was measured after $0-60 \mathrm{~min}$ incubation at $88^{\circ} \mathrm{C}$

polyethylene glycol 6000 , sodium chloride, 2-methyl2,4-pentanediol and Crystal screen cryo formulation) without any success. Precipitants alone, such as ammonium sulfate, PEG, sodium formate, sodium citrate, sodium chloride and MPD at different concentrations over a broad range of $\mathrm{pH}$ and protein concentration did not yield crystals suitable for X-ray structure determination. Extremely thin needle-like crystals were obtained from $48 \%$ ammonium sulfate solution at $\mathrm{pH} 7.5-8.3$ at $6{ }^{\circ} \mathrm{C}$ and were not of suitable dimensions for diffraction experiments. Not well-shaped crystals (Fig. 3,a) and diffracting to $9 \AA$ resolution were obtained at $20{ }^{\circ} \mathrm{C}$ from $38-40 \%$ ammonium sulfate solution at $\mathrm{pH} 7.5$ in the presence of $5 \%$ glycerol after two-three weeks and are very poorly reproducible. SDS/PAGE shows degradation of the enzyme after one week at $20^{\circ} \mathrm{C}$ and even crystals contain two polypeptide chains with molecular mass of about 100 and $96 \mathrm{kDa}$ (data not shown). Betterquality crystals of LeuRSTT were obtained under the following conditions: to prevent protein degradation $10 \mu 1$ drops containing $8-10 \mathrm{mg} / \mathrm{ml}$ LeuRS in $40 \mathrm{mM}$ Tris- $\mathrm{HCl}$, pH 7.5, $2 \mathrm{mM}$ DTT, $10 \mathrm{mM} \mathrm{MgCl}, 1 \mathrm{mM}$ $\mathrm{NaN}_{3}$, and $15 \%$ ammonium sulfate were equilibrated for $12-14$ hours at $6{ }^{\circ} \mathrm{C}$ against $800 \mathrm{ml}$ reservoir solution containing 54-58\% ammonium sulfate in $100 \mathrm{mM}$ Tris- $\mathrm{HCl}, \mathrm{pH}$ 7.5. After rapid precipitation of the macromolecules the drops were transferred to $12{ }^{\circ} \mathrm{C}$ and ammonium sulfate concentration was
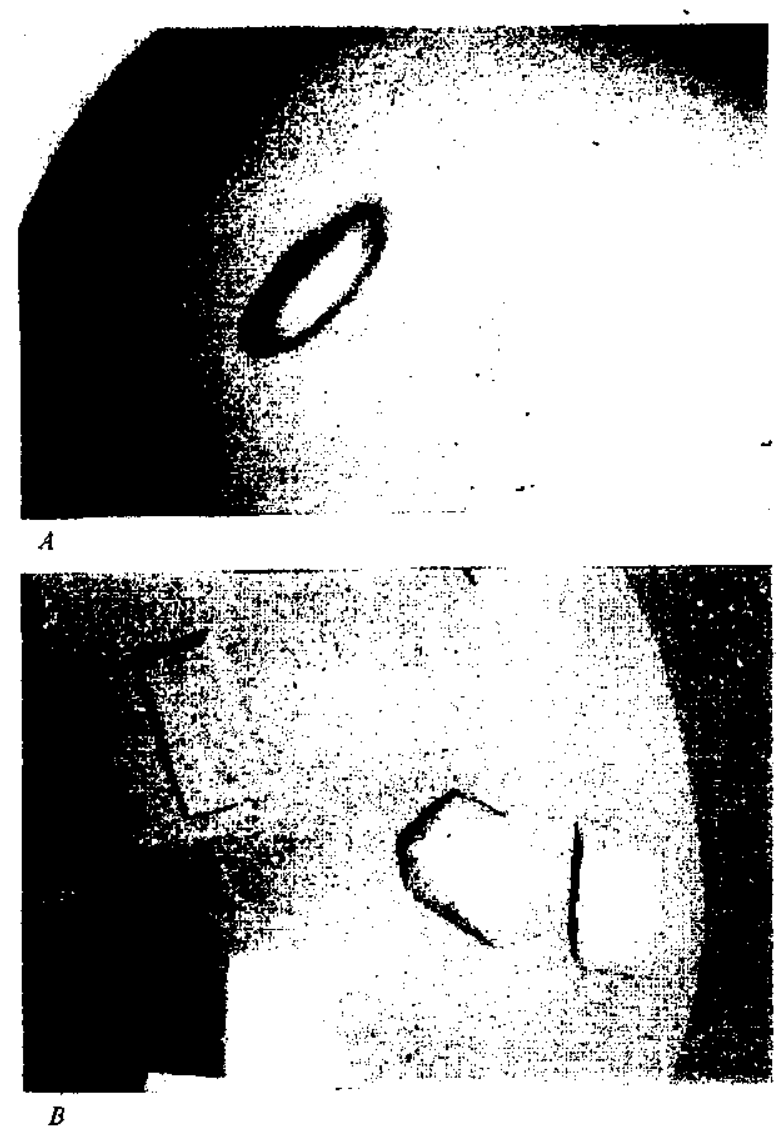

Fig. 3. Crystals of LeuRSTT: $a-$ not well-shaped crystals and diffracting to $9 \AA$ resolution; $b-$ crystalls obtained by crystallization from precipitate and diffracting to $3.5 \AA$ resolution

decreased to $40-42 \%$. Under these conditions well-shaped crystals appeared in two days and grew from precipitate rapidly over a $4-5$ days period to a maximum of $0,8 \mathrm{~mm}$ in the longest dimension (Fig. $3, b)$. After stabilization for one week against $48 \%$ saturated ammonium sulfate in $100 \mathrm{mM}$ Tris- $\mathrm{HCl}, \mathrm{pH}$ 7.5 crystals were mounted in quartz capillaries with a small amount of reservoir solution for X-ray diffraction measurements. These crystals diffract to $3.5 \AA$ resolution. The protein from washed and solubilized crystals as well as the protein used for crystallization was verified as full-length LeuRSTT by SDS/PAGE and enzymatic ability to aminoacylate tRNA. X-ray diffraction analysis of these crystals is under way. Small crystals of LeuRSTT in complex 
with tRNA ${ }^{\text {leu }}$ were obtained using ammonium sulfate as a precipitant but they were not of suitable dimensions for X-ray analysis. The gene for LeuRSTT has been recently cloned, sequenced end expressed in $E$. coli (Tukalo et al., unpublished results) and the work is under way to obtain high diffracting crystals of recombinant LeuRSTT and its complexes with substrates.

Acknowledgements. The research was supported in part by an International Research Scholar's award from the Howard Hughes Medical Institute.

Г. Д. Яремиук, О. І. Гудзера, С. П. Єгорова, Д. І. Рожко,

I. А. Крикливий, М. А. Тукало

Лейщил-тРНК синтетаза із Thermus thermophilus. Очищення i деякі властиності кристалів ферменту

Резюме

Лейцил-тРНК синтетазу із Thermus thermophilus (ЛейPCTT) виділено в гомогенному стані 3 використанням п'яти стадій очищення. Фермент охарактеризовано та отримано його кристали. Визначено молекулярну масу нативного і денатурованого білка Встановлено, що ЛейРСТТ являе собою мономер 3 молекулярною масою 101 кДа. Отриманому ферментові притаманна значна термостабільність і він зберігає $97 \%$ аміноациюююиоі активності після інкубацї протягом I год при температурі $88^{\circ} \mathrm{C}$. Кристали ЛейРСТТ одерхано методом дифузї парів із використанням як осаджувача розинну сульфату амонію.

А. Д. Яремчук, О. И. Гудзера, С. П. Егорова, Д. И. Рожко, И. А. Крикливый, М. А. Тукало

Јейцил-тРНК синтетаза из Thermus thermophilus. Очистка и некоторые свойства кристаллов фермента

Резюме

Лeйцил-тРНК синтетаза из Thermus thermophilus (JeйPCTT) выделена в гомогенном состоянии с использованием пяти стадий очистки. Фермент охарактеризован и получены его кристаллы. Определена молекулярная масса нативного и денатурированного белка. Установлено, что ЛейРСТТ представляет собой мономер с молекулярной массой 10І кДа. Полученный фермент обладает значительной термостабильностью и сохраняет $97 \%$ аминоаџилирующей активности после инкуба- чии в течение I ч при температуре $88^{\circ} \mathrm{C}$. Кристалиы ЛейРСТТ получены методом диффузии паров с использованием 6 качестве осадителя раствора сульфата аммония.

\section{REFERENCES}

1. Jakubowski H., Goldman E. Editing of errors in selection of amino acids for protein synthesis // Microbiol. Rev.-1992.56, N 3.-P. 412-429.

2. Lin L. Hale S. P., Schimmel $P$. Aminoacylation error correction // Nature (London).-1996.-384, N 6604.P. $33-34$.

3. Eriani G., Delarue M., Poch O., Gangloff J., Moras D. Partition tRNA synthetases into two classes based on mutually exclusive sets of sequense motifs // Nature (London).1990.-347, N 6289.-P. 203-206.

4. Cusack S., Berthet-Colominas C., Hartlein M., Nassar N. Leberman $R$. A second class of synthetase structure revealed by X-Ray analysis of $E$. coli seryl-tRNA synthetase at $2.5 \AA$ resolution // Nature (London).-1990.-347, N 6290.P. $249-255$

5. Asahara H., Himeno H., Tamura K., Hasegava $T$., Watanabe $K$. Shimizu $M$. Recognition nucleotides of Escherichia coll tRNA $^{\text {Leu }}$ and its elementfacilitating discrimination from tRNA ${ }^{\text {Ser }}$ and RNA $^{\text {Tyr }} / /$ J. Mol. Biol. $-1993 .-231$, N 2.-P. 219229.

6. Cusack S. Eleven down and nine to go // Nature Struct. Biol.-1995.-2, N 10.-P. 824-831.

7. Arnez J. G., Moras D. Structural and functional considerations of the aminoacylation reaction $/ /$ Trends Biochem. Sci.1997.-22, N 6.-P, 211-216.

8. Martinis S. A., Plateau P., Cavarelli J., Florentz C. Aminoacyl-tRNA synthetases: A new image for a classical family // Biochimie.-1999.-81, N 7.-P. 683-700.

9. Laemmli U. K Cleavage of structural proteins during the assembly of the head of bacteriophage T4// Nature. -1970 .227, N 5259.--P. 680-685.

10. Chen J., Li Y., Wang E., Wang Y. High-level expression and single-step purification of leucyl-tRNA synthetase from Escherichia coli // Protein Exp. Purif.-1999.-15, N 1.P. $115-120$.

11. Mazauric M. H., Reinbolt J., Lorber B., Ebel C., Keith G., Giege $R$., Kern $D$. An example of non-conservation of oligomeric structure in prokaryotic aminoacyl-tRNA synthetases. Biochemical and structural properties of glycyl-tRNA synthetase from Thermus thermophilus // Eur. J. Biochem.1996.-241, N 3.-P. 814-826. 